\title{
ТЕРМІНОГРАФІЧНІ ТРАДИЦІЇ І НОВАТОРСТВО В УКРАЇНСЬКІЙ ТЕРМІНОЛОГІЧНІЙ ЛЕКСИКОГРАФІЇ
}

У статті розкрито зміст понять «термінографічна традиція», «новаторство в термінографії. Здійснено аналіз традиційних $і$ новаторських ознак украӥнської термінограбії (50-і рр. XIX cm. - початок XXI cm.) на основі врахування комплексу параметрів систематизації (класифікаціі) термінологічних словників. Установлено, що українська термінограбія більшою мірою наслідує кращі їі традиціі і меншою - удається до новаторства. Наголочено, що новаторські підходи до створення термінологічних словників можуть формувати базу термінограбічного досвіду, збагачуючи традичї спеціальної лексикограбії.

Ключові слова: термінологічний словник, українська термінограбія, термінографічна традиція, новаторство в термінограбії, параметри систематизачї термінологічних словників.

Petrova T. Terminographic Traditions and Innovations in Ukrainian Terminological Lexicography. Terminological lexicography of the beginning of the XXI century requires the consideration of the opposition 'traditions-innovations', i. e. the analysis of the practical expediency and effectiveness of inheritance of traditions and innovative activities.

The purpose of the research is to identify traditional and innovative features of national terminography; the tasks are as follows: 1) to give a precise definition of the terms «terminographic tradition» and «innovation in terminography»; 2) to develop a parametric system of analysing terminographic traditions; 3) to study special sources for traditional or innovative reflection of lexicographic parameters in them; 4) to determine the role of tradition and innovation in Ukrainian terminography.

Terminographic tradition is a set of the most stable, long-established features and parameters of various types of special works. Innovation in terminography is a non-traditional representation of certain parameters of professional dictionaries in order to modernize and improve terminographic products.

To a greater extent national terminography follows the best traditions as well as it implements innovative actions to a lesser extent, in particular: 1) the creation of specialized dictionaries and dictionaries of narrow specialization and at the same time the development of new types of universal, general scientific, and multidisciplinary dictionaries; 2) the predominance of interlingual dictionaries, and at the same time, the increase of the number of languages for special translation, the represantation of Ukrainian language as a source language and emphasis on its state status; 3) the instability of traditions of codification norms in dictionaries; 4) incomplete description 
of branch terminology both in specific dictionaries, and in dictionaries-minimums, as well as in the registers of universal, general scientific, and multidisciplinary editions; 5) the usual alphabetical principle of placing terms in dictionaries, and less common principle of alphabetically nested and thematic arrangement; 6) harmony with the world tradition of compiling paper dictionaries, and at the same time the beginning of creation of electronic sources.

The grounds for innovative activities are terminographic traditions, the existence of which as a system ensures the stability of the creation of Ukrainian special vocabulary.

Key words: terminological dictionary, Ukrainian terminography, terminographic tradition, innovation in terminography, systematization parameters of terminological dictionaries.

\section{Вступ}

Тривала історія української термінографії і значний обсяг накопичених нею знань щодо створення спеціальних словників дають змогу стверджувати, що все це стало можливим завдяки клопіткій праці українських термінографів, а також наявності сформованої національної традиції. Термінограббічну традицію інтерпретуємо як процес збереження починань і їх передавання як естафети наукового досвіду укладання фахових словників, що є дзеркалом національної науки й інтелектуального рівня розвитку етносу. «Повага до традиції, іiі знання і наслідування, знання української мови як рідної і як державної - це важлива умова розвитку суспільства, його належного поступу, становлення державності» (Космеда \& Осіпова, 2010: 10).

Традиція відіграє особливу роль у формуванні принципів і засад створення фахових словників, це запорука примноження надбань термінографіі. Новаторство - виклик традиції або іï осучаснення, «оживлення». Сьогодні термінологічна лексикографія потребує усвідомлення опозиції 'традиції - новаторство', тобто аналізу доцільності й ефективності наслідування і новаторської діяльності.

Українські вчені приділяють увагу дослідженню української лексикографічної спадщини, зокрема Ю. Поздрань (Поздрань, 2013) і М. Яремій (Яремій, 2015) вивчають лексикографічну традицію на матеріалі окремих словників авторитетних укладачів; В. Дубічинський відстежує традиції лексикографії, аналізуючи іiі минуле й теперішнє (Дубичинский, 2013). Білоруський дослідник В. Щербін також описує традицію національної лексикографії з огляду на ії історію (Щербин, 
2013); англійський металексикограф Г. Джеймс - лексикографічну традицію на матеріалі словникарської діяльності Індії (James, 1994: 2183). Попри широке вивчення українськими та зарубіжними науковцями лексикографічних традицій, дослідженню історії і новаторства української термінографії досі не приділено належної уваги, що й визначає актуальність цієї наукової розвідки.

Мета цієї студії - виявити традиційні й новаторські ознаки національної термінографії (50-і pp. XIX ст. - початок XXI ст.); іiї завдання - 1) дати точне визначення понять «термінографічна традиція» i «новаторство в термінографії», 2) виробити параметричну систему аналізу термінографічних традицій, 3) дослідити спеціальні джерела щодо традиційного чи новаторського відображення в них лексикографічних параметрів; 4) визначити роль традиції і новаторства в українській термінографії.

\section{Методи дослідження}

Для досягнення мети й завдань застосовуємо низку методів, серед яких структурний (для вивчення будови термінологічних словників), лексикографічного аналізу (для визначення й характеристики лексикографічних параметрів словників), описовий (для систематизування параметрів спеціальних джерел) і порівняльний (для зіставлення словників за параметрами, що визначають їхні види).

\section{Виклад основного матеріалу}

Традиція - це одночасно й надбання минулого, і основа формування сучасного й майбутнього. Поняття «традиція» функціює в культурі, літературі, мистецтві, науці, освіті, політиці, релігії тощо. Традиція визначає різноманітні форми впливу минулого на сучасне й майбутнє, тобто традиція — це «буттєва єдність часу та здійснення майбутнього на основі постійного осучаснення минулого» (Філософський енциклопедичний словник, 2002: 646).

Опис історії розвитку системи спеціальних праць, поступу теоретичних знань і напрацювання практичних умінь щодо укладання українських термінологічних словників, без сумніву, $є$ національною термінографічною традицією. Українська термінографічна традиція - це сукупність найбільш стійких, усталених упродовж тривалого часу ознак і параметрів різних видів спеціальних праць, створених українськими словникарями й наслідуваних наступними 
поколіннями. Новаторство в термінографії - нетрадиційне репрезентування певних параметрів фахових словників, відхиляння від прийнятих засад і принципів їхнього створення, тобто термінографічні починання, до яких вдаються вчені з метою поліпшення термінографічної продукції.

Світовій науковій літературі відома система видів лексикографічних традицій. Спробуємо узагальнити виокремлені різновиди цих традицій і виділити параметри, на основі яких, як видається, їх диференціюють: 1) 'науковий / навчальний потенціал словника' а) академічна традиція побудови словника (Виноградов, 1977: 227), що реалізується в тлумачних словниках академічного типу; б) університетська традиція побудови словника (Щербин, 2013: 51), виникнення якої зумовлене поширенням праць навчального характеру; 2) 'геополітична характеристика' - а) основна лексикографічна традиція; б) альтернативна лексикограбічна традиція. Ці два останні види виділив англійський металексикограф Г. Джеймс під час вивчення особливостей словникарської діяльності Iндії (James, 1994: 2183). В. Щербін у білоруській лексикографії XX ст. також відстежує основну («сукупність стійких словникових характеристик, відображених у довідкових виданнях, опублікованих на території Білорусі») й альтернативну («типові характеристики емігрантських словників білоруської мови») лексикограбічні традицї (Щербин, 2013: 51).

Якщо розглядати названі види лексикографічної традиції в термінографії, то виділяти навчальний вид термінологічних словників, а відповідно, і університетську традицію побудови словника недоречно, оскільки кожний фаховий словник за своєю суттю $€$ науковим виданням, а за призначенням - навчальним, систематизувальним джерелом. До того ж поняття «академічний словник» ототожнюють з поняттям «нормативний словник», зокрема Л. Щерба академічним називав нормативний словник, пояснюючи, що, коли 6 справа була у формальній назві чи виданні, то кожний словник, створений в Академії, уважався б академічним (Щерба, 1974: 265-266). Відповідно, такий розподіл доцільно здійснювати не за параметром 'побудова словника', а за 'місцем створення', тобто 'місцем словникарської діяльності його авторів’. Між тим, якщо оцінювати якість і принцип побудови термінографічних джерел, що впорядковані в установах академічного рівня чи університетах, то іноді між ними не можна 
віднайти різниці, оскільки рівень праць залежить від компетентності його упорядників.

Деякі принципи укладання словників, які обгрунтовував Б. Грінченко у «Словарі української мови», Ю. Поздрань простежує в «Російсько-українському словнику» за ред. А. Кримського й С. Єфремова та виокремлює такі успадковані лексикографічні традиції: 1) наявність чіткої наукової концепції словника; 2) повне й точне відтворення лексикону епохи; 3 ) грунтовна джерельна база словника; 4) об'єктивне фахове опрацювання мовного матеріалу та обгрунтований реєстр словника; 5) нормативність словника (Поздрань, 2013: 39-43).

Ураховуючи викладене вище, власні напрацювання й авторський досвід, уважаємо, що відстеження в українському спеціальному словникарстві ознак термінографічної традиції і новаторських підходів доречно здійснювати, спираючись на вивчення специфіки репрезентування (1) параметрів, що формують основу систематизування фахових видань (a/ тематичний обсяг; б/ спосіб семантизування й призначення словника; в/ функція словника; г/ обсяг словника; д/ порядок розміщення лексичного матеріалу; е/ носії інформації та ін.), а також (2) параметрів мега-, макро- й мікроструктури спеціальних джерел.

Укладання термінологічних словників від 50-х pp. XIX ст. до 20-х рр. ХХ ст. здійснюють без вироблених теоретичних настанов. Відповідно, у 20-30-і pp. XX ст. науковці ІУНМ поєднували практичну роботу з теоретичним осмисленням побудови терміносистем. На засіданнях методологічної комісії ІУНМ розробляли засади створення спеціальних джерел різних типів. Підсумком цієї роботи стало опублікування «Інструкції для укладання словників ІУНМ» у першому випуску «Віснику ІУНМ» (1928). Названа інструкція, без сумніву, $€$ результатом прогресивної і новаторсвкої на той час діяльності ії невтомних розробників, що навіть сьогодні $є$ актуальною, а ії положення можуть лягти в основу перспективи украӥнських термінограбічних традицій.

У цій статті розглянемо за названими вище параметрами процес систематизування термінологічних словників, з'ясуємо, наскільки наслідуються традиції й запроваджується нове в термінографії протягом 50-х pp. XIX ст. - початку XXI ст.

1. Тематичний обсяг. У спеціальних джерелах в окреслений період відстежуємо тенденцію розширення тематичного обсягу. Словники 
кінця XIX ст. описують переважно лексику природничих наук, видання 10-х рр. XX ст. охоплюють не лише природничу, а й лінгвістичну термінологію та ін. Звісно, нині ще не всі терміносистеми національних галузей знань описані й кодифіковані, але вийшли друком словники з археології, архітектури, бджільництва, геральдики, гербології, гончарства, графіки, екології та охорони природи, землевпорядкування та кадастру, землеробства, естради, залізничної та інженерної справ, інформатики, пожежної техніки, радіотехніки, управління відходами тощо. До того ж, якщо більшість словників 50-х pp. XIX ст. 80-х pp. XX ст. належить до галузевих за тематичним обсягом, то від 90-х рр. ХХ ст. з'являються нові види 'за широтою охоплення термінологічної лексики': універсальні $i^{1}$, загальнонаукові ${ }^{2}$, багатогалузеві ${ }^{3}$, вузькогалузеві $i^{4}$ Поява універсальних, загальнонаукових і багатогалузевих словників спричинена інтенсивним розвитком та перехрещуванням терміносистем багатьох суміжних галузей знань, відповідно, створення вузькогалузевих видань - прагненням окреслити чіткі межі окремої підсистеми описуваної науки.

2. Спосіб семантизування та призначення словника. Становлення національного термінологічного словникарства починається з видання 1851 р. словника дефінітивного типу - «Словничка бджільницьких термінів» О. Покорського-Жоравка. Дефінітивний (тлумачний) термінологічний словник - це одномовне видання, центральним параметром його мікроструктури є 'дефініція', тобто має місце семантизація. "Дефініція - це логічне визначення поняття, встановлення його змісту і відмінних ознак. Це логіко-поняттєва категорія, характерна для енциклопедичних та термінологічних словників і зазвичай орієнтована на науково-галузеве бачення дійсності» (Широков, 2004: 98). Однак дефінітивні термінографічні праці в подальші роки як вид не засвідчені. Лише від 90-х рp. XX ст. фахові тлумачні словники починають активно друкувати.

1 Гейченко, В. В., Завірюхіна, В. М., \& Зеленюк, Р. О. (1998). Російсько-український словник наукової термінології: Математика. Фізика. Техніка. Науки про Землю та Космос. Київ: Наук. думка.

2 Симоненко, Л. О. (Заг. ред.). (2004). Українсько-російський словник наукової термінології. Київ; Ірпінь: ВТФ «ПЕрун».

3 Медведєв, В. В. (Гол. ред.), \& Міхновська, А. Д. (Ред.). (1998). Термінологічний словник з питань грунтознавства, агрохімії і меліорації грунтів. Харків: Ін-т грунтознавства та агрохімії ім. О. Н. Соколовського УААН.

4 Фурдичка, О. І. (Ред.). (2007). Словник-довідник з агроекології. Київ: Основа. 
Більшості сучасних термінографічних праць, що розкривають зміст спеціальних понять через дефініювання, характерні, за нашими спостереженнями, (1) невідповідність логічним і лінгвістичним вимогам, (2) відсутність єдиного підгрунтя якісного репрезентування змісту терміна, (3) неврахування різного обсягу змісту понять (деякі потребують подання енциклопедичної інформації, формул) тощо. Це засвідчує несформованість традиції дефініювання, відсутність орієнтування на різні типи дефініцій (описові, родо-видові, синонімні та ін.) (див. про це: Петрова, 2018: 160-177).

Від середини XIX ст. і дотепер традиційно домінують перекладні словники. При цьому в таких працях до 10-х pp. XX ст. українська мова функціювала в зоні перекладу, вихідними ж мовами переважно були латинська, німецька, російська. Термінографічні джерела 20-30-х рр. ХХ ст. головно перекладали терміни з російської мови на українську, нині ж поширено залучають для спеціального перекладу англійську, німецьку, французьку, іспанську, грузинську та інші мови. Як і тоді, сьогодні в українській термінографії насамперед створюють двомовні перекладні словники, однак поодиноко укладають три-, чотири-, п'яти- й шестимовні ${ }^{5}$ видання. 3'являється й новий тлумачно-перекладний вид спеціальних джерел ${ }^{6}$, що $є$ новаторським. Крім того, продовжено традицію створення ілюстративних словників ${ }^{7}$, яких спеціальні поняття розкривають через застосування ілюстративного параметра. Результатом новаторської словникарської діяльності $є$ видання унікального за багатьма параметрами (тематикою, художнім оформленням, обсягом, кількістю мов і термінів) «Ілюстрованого словника з геральдики» М. Стародубцева 8 .

5 Патон, Б. Є. (Гол. наук. ред.), \& Кашакашвілі, Г. В. (Гол. ред.). (2014). Словник металургійних термінів: у 2 т.: Українсько-грузинсько-російсько-англійсько-німецько-французький. НАН України, РАН, НАН Грузії, РАПН, Грузинський технічний ун-т. 1 електрон. опт. диск (DVD-ROM). Київ: Фенікс.

6 Павловський, М., Петрух, Л., \& Головко, І. (Ред.). (1995). Українсько-латинсько-анıлійський медичний тлумачний словник: у 2 т. Львів: Видавнича спілка «Словник», 1995; Іваницький, Р., \& Кияк, Т. (1995). П’ятитомний тлумачний словник з інформатики. Київ: ВІПОЛ.

7 Яната, О. (1926). Рослина і іï життя: Друге українське видання. 3154 малюнками та словничком ботанічних термінів. Харків: Всеукр. с.-г. вид-во «Радянський селянин»; Клименюк, Т., Проскуряков, В., \& Ковальчук, К. (2019). Ілюстрований словник архітектурних термінів. Львів: Вид-во Львівської політехніки.

8 Стародубцев, Н. Н. (1996). Иллюстрированный словарь по геральдике: 1005 терминов на русском, украинском, английском, эсперанто, французском, немецком, латинском языках. Донецк: Донеччина. 
У цьому джерелі репрезентовано понад 1 тис. термінів сімома мовами (російською, українською, англійською, есперанто, французькою, німецькою, латинською), відповідно, термінографія поповнилася новим видом словника - ілюстративно-перекладним.

Найпершою галузевою енииклопединню працею вважають «Ілюстрований сільськогосподарський словник» (1891-1895) С. Богданова. У період «золотого десятиліття» також побачила світ «Енциклопедія сільського господарства» (1927). Лише 1973 р., майже через пів століття, надруковано украйнську галузеву енциклопедію 9 під керівництвом В. Глушкова, що стала першою у світі енциклопедією з кібернетики. Вона містить майже 1700 статей з інформатики, кібернетики, обчислювальної техніки. Над іï створенням працювали близько 600 науковців та спеціалістів з різних галузей знань та зі 102 наукових і виробничих установ Радянського Союзу. Сучасна термінографія продовжує наслідувати ці починання, зокрема від 90-х рр. ХХ ст. й дотепер упорядковано галузеві енциклопедії (з економіки, лісівництва, музики, психології, політики, соціології, фольклору, юриспруденції тощо), вузькогалузеві (з термометрії, аграрних фінансів, нафтогазової промисловості тощо) та міжгалузеві. Наявність енциклопедій визначає рівень наукових досягнень українського народу в різних галузях знань.

3. За функцією термінологічні словники поділяють на інвентаризаційні й нормативні. Інвентаризаційні джерела подають перелік терміноодиниць певної науки. Такими виданнями I. Казимирова вважає історико-термінологічні праці (Казимирова 201: 24), але вони рідкісні. Кожний спеціальний словник є нормативним ${ }^{10}$, оскільки він повинен виконувати нормувальну, кодифікаційну, уніфікаційну, рекомендаційну й популяризаційну функції. Між тим більшість сучасних фахових джерел потребують перегляду щодо дотримання мовних норм у термінології і правил чинного українського правопису. Зокрема, у словниках, виданих протягом 1991-2020 рр., відстежуємо такі традииї кодифікування мовних норм: 1) наслідувальна (1991 р. кінець 2000-х рр.) - тяглість термінотворення за російськомовним зразком, функціювання «мовних покручів», кальок; 2) відроджувальна (національна) (2000 2010рр.) - а) надмірний пуризм (наслідування

9 Глушков, В. М. (Відп. ред.). (1973). Енциклопедія кібернетики: у 2 т. Київ: Голов. редакція Укр. радянської енциклопедії та АН УРСР.

10 Березуцький, В. В., \& Васьковець, Л. А. (2013). Тлумачний словник нормативних термінів із дисципліни «Безпека життєдіяльності»: навч. посібник. Харків: Підручник НТУ «ХПІ». 
традицій 20-30-х рр. XX ст., розбудовування термінології на національному грунті, повне неприйняття чужомовних одиниць); б) поміркований пуризм (послаблене наслідування традицій 20-30-х рр. $\mathrm{XX}$ ст., уникання лише тих запозичень, що мають відповідники в рідній мові тощо); 3) міжнаціональна (2011-2014 рр.) - орієнтування на інтернаціональний характер термінів, калькування чужомовних одиниць (головно англіцизмів) з позначуваними поняттями; 4) комnромісна (поміркована) (2015-2020рр.) - уникнення зайвих запозичень і пошук власномовних одиниць (Петрова, \& Кримець, 2018: 193-196). Отже, під час створення нормативних словників важливо однаковою мірою враховувати національні й закордонні традиції, надавати перевагу питомим одиницям, запозичувати терміни безпосередньо з мови-оригіналу, дотримуватися поміркованих пуристичних поглядів, оскільки мовна й термінологічна норми формуються поступово.

4. За обсягом спеціальні видання поділяють на повні (понад 80 тис. од.), короткі (до 30 тис. од.) і словники-мінімуми (менше 30 тис. од.). Кожен упорядник прагне створити повний термінологічний словник, вичерпно й усеохопно описати термінологію певної галузі. Однак термінографія часто не встигає за поступом науки й техніки. Нині в національному словникарстві все ще наслідується традиція створювати повні ${ }^{11}$, а також короткі друковані словники ${ }^{12}$, що можуть містити, наприклад, 125 терміностатей ${ }^{13}$. Активно з'являються й короткі інтернет-джерела ${ }^{14}$, що $є$ новаторством. Однак їхній обсяг указує на неповний опис спеціальної мови певної галузі. Між тим існують і словники-мінімуми, що призначені переважно для вивчення спеціальної лексики фаху в $3 \mathrm{BO}^{15}$.

11 Благовєщенський, О. С. (Ред.). (2002). Великий російсько-український політехнічний словник. Близько 160000 слів та словосполучень. Київ: Чумацький шлях.

12 Жигадло, І. (1918). Короткий московсько-український словник судівництва та діловодства (бл. 3500 слів). Полтава: Вид-во Полтав. Укр. Правничого Т-ва; Єрмоленко, С. Я., Бибик, С. П., \& Тодор, О. Г. (2001). Українська мова. Короткий тлумачний словник лінгвістичних термінів. Київ: Либідь; Ходанич, Л., \& Палько, Т. (2018). Професійне мовлення вчителя. Короткий словник термінів. Ужгород: Закарпат. ін-т післядиплом. пед. освіти.

13 Ахвердова, М. Й., Муравйова, В. М., \& Набхан, Ю. О. (2011). Короткий тлумачний словник термінів з УДК. Київ: Книжкова палата України.

14 Короткий словник термінів інтернет-маркетингу для власників бізнесу. (2019). Узято 3 https://ag.marketing/slovnik-terminiv-internet-marketingu/; Міжнародний менеджмент. Короткий словник термінів. (2002). Узято з https://library.if.ua/book/142/9543.html.

15 Мисак, О. Т., \& Огерчук, С. М. (2016). Тлумачний словник-мінімум термінів 3 циклу дисциплін загальної підготовки. Львів. 
5. Принции розміщення термінів у словнику має неабияке значення. Звиклим принципом побудови термінологічних словників $€$ алфавітници, менш поширені - алфавітно-гніздовий ${ }^{16}$ і тематичний ${ }^{17}$ (тематично-алфавітний, ідеографічний). Як перспективний розглядаємо тематичний приниип побудови фахових словників, утім система знань швидко розвивається, відповідно, може змінитися теоретичне підгрунтя виділення розділів і підрозділів у системі наукової галузі, що спричинить перегрупування терміноодиниць за темами.

6. За носієм інформації в українській науці продовжується реалізація традиціі укладання "ручних» (паперових) термінограбічних джерел, як і в усьому світі, тобто це світова традиція. Однак друковані версії виходять із часовим запізненням і не можуть оперативно оновлюватися. Наприклад, 2004 р. розпочато розроблення системи для укладання електронних (комп'ютерних) словників. На той час це було новаторством в українській термінографії. Зокрема для укладання електронних двомовних тлумачних спеціальних праць створено системy PolyDic 1.0, за допомогою якої укладено електронні версії п'яти словників 3 термінографічної серії “СловоСвіт» ${ }^{18}$. Електронні словники мають переваги: простота у використанні; зручний пошук; можливість подавати терміни за гніздовим принципом, створювати спливні інформаційні вікна для тлумачення словникових позначок тощо. Серед їхніх недоліків назвемо обмеженість кількості мов у перекладних словниках, а також успадкування деяких проблем друкованих праць, зокрема неповнота видання й підтримання його в актуальному стані.

Виконаний аналіз засвідчує, що словникарська діяльність здійснюється на тлі загальної сукупності вже створених праць, тобто на грунті традицій. Часто починання щодо укладання термінологічних словників лягають в основу термінографічного досвіду, збагачуючи традиції української спеціальної лексикографії.

16 Волинець, А. Р., Гринь, Ю. О., Короп, Ю. О., \& Харчук, О. В. (1995). Російсько-український фізкультурно-спортивний словник. Київ: Академія праці і соц. відносин.

17 Диньовський, Д. М. (1993). Короткий українсько-російський словник з фізичної культури і спорту. Київ: Просвіта.

18 «Російсько-український та українсько-російський словник термінів будівництва й архітектури», «Російсько-український словник з інженерних технологій», «Російсько-український коксохімічний словник», «Словник-довідник термінології музейництва» та «Англійсько-український словник з радіоелектроніки». 


\section{Висновки}

Вивчення спеціальних джерел за параметрами їхнього систематизування показує, що національна термінографія більшою мірою наслідує кращі традиції і меншою - здійснює новаторські дії, зокрема: 1) 'тематичний обсяг' - створення галузевих і вузькогалузевих словників, а також розроблення нових видів - універсальних, загальнонаукових, багатогалузевих; 2) 'спосіб семантизування й призначення словника' - переважання перекладних словників, а водночас збільшення кількості мов для спеціального перекладу, підкреслення державного статусу української мови, тобто репрезентування іiі як вихідної, а не в зоні перекладу; 3) 'функція словника' - нестійкість традицій кодифікування норм у термінологічних словниках, що зумовлено впливом мовних і позамовних чинників у різні періоди розвитку української термніографії; 4) 'обсяг словника' - неповне репрезентування галузевих термінологій і в окремих словниках, і в словниках-мінімумах, і як складників у реєстрі універсальних, загальнонаукових та багатогалузевих видань; 5) 'порядок розміщення лексичного матеріалу' - домінування алфавітного принципу розміщення термінів, непоширеність алфавітно-гніздового й тематичного, що можуть формувати перспективу термінографії; 6) 'носії інформаціï - традиція упорядкування паперових словників (що є і світовою традицією) конкурує з починаннями щодо створення електронних словників.

Отже, основою для новаторської діяльності слугують термінографічні традиції, існування яких забезпечує стабільність функціювання українського спеціального словникарства. Отримані результати аналізу дають змогу виявити «міцне підгрунтя» термінографічної діяльності, відстежити оновлені параметри, а також визначити ті, що потребують новаторського осмислення. Перспективи дослідження пов’язуємо з вивченням традиційних і новаторських підходів в українському спеціальному словникарстві, обираючи для аналізу специфіку репрезентування параметрів мега-, макро- й мікроструктури термінографічних джерел.

\section{ЛІТЕРАТУРА}

1. Виноградов, В. В. (1977). Избранные труды. Лексикология и тексикография. Москва: Наука. 2. Дубичинский, В. (2013). Лексикография украинского языка: прошлое и настоящее. В Славянская тексикография (с. 251-309). Москва: Азбуковник. 
3. Інструкція для укладання словників ІУНМ. (1928). Вісник IУНМ, 1, 66-72. 4. Казимирова, I. А. (2015). Словник авторської фахової метамови в типології історикотермінологічних словників. Система і структура східнослов'янських мов, 8, 23-31. 5. Космеда, Т., \& Осіпова, Т. (2010). Тлумачний словник комунікативного призначення як породження сучасної прагматично зорієнтованої наукової парадигми. Лексикографічний бюлетень, 19, 7-24. 6. Петрова Т. О., \& Кримець, О. М. (2018). Розвиток українької науково-технічної термінології сьогодні: напрями і перспективи. Key Issues of and Sciences: Development Prospect for Ukraine and Poland: International Multidisciplinary Conference (20-21 July, 2018, Stalova Wola, Republik of Poland) (p. 193-196). Stalova Wola: Izdevnieciba «Baltija Publishing». 7. Петрова, Т. О. (2018). Фітомеліоративна термінологія сучасної української мови та ї відображення в термінологічному словнику комбінованого типу. Харків: ТОВ «ТПГ». 8. Поздрань, Ю. В. (2013). Лексикографічні традиції Б. Д. Грінченка в Російсько-українському словнику за редакцією А. Ю. Кримського та С. О. Єфремова. Лексикограббічний бюлетень, 22, 37-45. 9. Шинкарук, В. І. (Голов. ред.). (2002). Філособський еницклопедичний словник. Київ: Абрис. 10. Широков, В. А. (2004). Феноменологія лексикографічних систем. Київ: Наук. думка. 11. Щерба, Л. В. (1974). Языковая система и речевая деятельность. Ленинград: Наука. 12. Щербин, В. (2013). Белорусская лексикографическая традиция: история и современность. Славянская тексикография (с. 21-61). Москва: Азбуковник. 13. Яремій, М. Р. (2015). Традиції та тенденції в українській лексикографії кінця ХІХ ст. - початку XX ст. (на матеріалі російсько-українських словників М. Левченка та М. Уманця (Комарова) I. А. Спілки). Наук. пр. Кам'янець-Под. наи. ун-ту імені Івана Огієнка. Філологічні науки, 38, 376-382. 14. James, G. (1994). Lexicography, Indian. The Encyclopedia of Language and Linguistic (p. 4). Oxford.

\section{REFERENCES}

1. Vinogradov, V. V. (1977). Izbrannye trudy. Leksikologiya i leksikografiya [Selecta. Lexicology and Lexicography]. Moskva: Nauka [in Russian]. 2. Dubichinskij, V. (2013). Leksikografiya ukrainskogo yazyka: proshloe i nastoyashhee [Lexicography of the Ukrainian Language: Past and Present]. In Slavyanskaya leksikografiya - Slavic lexicography (s. 251-309). Moskva: Azbukovnik [in Russian]. 3. Instruktsiia dlia ukladannia slovnykiv IUNM. (1928). [Instruction how to Compile a Dictionary IUSL]. Visnyk IUNM - Bulletin of the Institute of Ukr. Scientific Language, 1, 66-72 [in Ukrainian]. 4. Kazymyrova, I. A. (2015). Slovnyk avtorskoi fakhovoi metamovy v typolohii istoryko-terminolohichnykh slovnykiv [Dictionary of the Author's Professional Metalanguage in the Typology of Historical and Terminological Dictionaries]. Systema i struktura skhidnoslovianskykh mov - System and structure of East Slavic languages, 8, 23-31 [in Ukrainian]. 5. Kosmeda, T., \& Osipova, T. (2010). Tlumachnyi slovnyk komunikatyvnoho pryznachennia yak porodzhennia suchasnoi prahmatychno zoriientovanoi naukovoi paradyhmy [Definition Dictionary for Communicative Purpose as a Product of a Modern Pragmatically Oriented Scientific Paradigm]. Leksykohrafichnyi biuleten - Lexicographic bulletin, 19, 7-24 [in Ukrainian]. 6. Petrova, T. O., \& Krymets, O. M. (2018). Rozvytok ukrainskoi naukovotekhnichnoi terminolohii sohodni: napriamy i perspektyvy [Development of Ukrainian Scientific and Technical Terminology Today: Directions and Trends]. Key Issues of and Sciences: Development Prospect for Ukraine and Poland: International Multidisciplinary Conference (20-21 July, 2018, Stalova Wola, Republik of Poland) (pp. 193-196). Stalova Wola: Baltija Publishing [in Ukrainian]. 7. Petrova, T. O. (2018). Fitomelioratyvna 
terminolohiia suchasnoi ukrainskoi movy ta yii vidobrazhennia v terminolohichnomu slovnyku kombinovanoho typu [Phytomeliorative Terminology of the Modern Ukrainian Language and Its Representation in the Terminological Combined Dictionary]. Kharkiv: TOV «TPH» [in Ukrainian]. 8. Pozdran, Yu. V. (2013). Leksykohrafichni tradytsii B. D. Hrinchenka v Rosiisko-ukrainskomu slovnyku za redaktsiieiu A. Yu. Krymskoho ta S. O. Yefremova [Lexicographic traditions of B. Grinchenko in the Russian and Ukrainian Dictionary edited by A. Krymsky and S. Efremov]. Leksykohrafichnyi biuleten - Lexicographic bulletin, 22, 3745 [in Ukrainian]. 9. Shynkaruk, V. I. (Ed.). (2002). Filosofskyi entsyklopedychnyi slovnyk [Philosophical Encyclopedic Dictionary]. Kyiv: Abrys [in Ukrainian]. 10. Shyrokov, V. A. (2004). Fenomenolohiia leksykohrafichnykh system [Phenomenology of Lexicographic Systems]. Kyiv: Nauk. dumka [in Ukrainian]. 11. Shherba, L. V. (1974). Yazykovaya sistema $i$ rechevaya deyatel'nost' [Language System and Oral Activity]. Leningrad: Nauka [in Russian]. 12. Shherbin, V. (2013). Belorusskaya leksikograficheskaya tradiciya: istoriya i sovremennost' [Belarusian Lexicographic Tradition: History and Modernity]. In Slavyanskaya leksikografiya - Slavic lexicography (pp. 21-61). Moskva: Azbukovnik [in Russian]. 13. Yaremii, M. R. (2015). Tradytsii ta tendentsii v ukrainskii leksykohrafii kintsia XIX st. - pochatku 20 st. (na materiali rosiisko-ukrainskykh slovnykiv M. Levchenka ta M. Umantsia (Komarova) I. A. Spilky) [Traditions and Tendencies in the Ukrainian Lexicography of the XIX-th Century - Beginning of the XX-th Century (on the materials of the Russian and Ukrainian dictionaries of M. Levchenko and M. Umantsya (Komarova) I. Spilki)]. Nauk.pr. Kamianets -Pod. nats. un-tu imeni Ivana Ohiienka. Filolohichni nauky - Scientific works of Ivan Ogienko Kamyanets-Podilsky National University.Philological sciences, 38, 376-382 [in Ukrainian]. 14. James, G. (1994). Lexicography, Indian. The Encyclopedia of Language and Linguistic (p. 4). Oxford [in English].

Петрова Тетяна Олексіївна - кандидат філологічних наук, доцент, доцент кафедри мовних дисциплін, Харківський національний аграрний університет імені В.В. Докучаєва, Харківська область, Харківський район; п/в «Докучаєвське - 2», 62483, Україна.

Tel.: +38-095-574-76-41

E-mail: t-petrova@ukr.net

http://orcid.org/0000-0002-9534-9891

Petrova Tetiana Oleksiivna - Ph.D. in Philology, Docent, Associate Professor at the Department of Linguistic Disciplines, V. V. Dokuchaiev Kharkiv National Agrarian University, Kharkiv region, Kharkiv district; p/o «Dokuchaievske - 2», 62483, Ukraine.

Надійшла до редакції 12 вересня 2020 року

\section{CITATION}

ДСТУ 8302:2015: Петрова Т. О. Термінографічні традиції і новаторство в українській термінологічній лексикографіі. Лінгвістичні дослідження: зб. наук. пр. Харк. нац. пед. ун-ту імені Г. С. Сковороди. Харків, 2020. Вип. 53. С. 209-221. DOI: https:// doi.org/10.34142/23127546.2020.53.19

APA: Петрова, Т. О. (2020). Термінографічні традиції і новаторство в українській термінологічній лексикографії. Лінгвістичні дослідження, 53, 209-221. DOI: https://doi.org/10.34142/23127546.2020.53.19 